\title{
Erratum to: Shaking the Foundations of the Law: Some Legal Issues Posed by a Detection of Extra-Terrestrial Life
}

Frans G. von der Dunk

Erratum to:

"Shaking the Foundations of the Law: Some Legal Issues

Posed by a Detection of Extra-Terrestrial Life" in

J.S.J. Schwartz and T. Milligan (eds.), The Ethics

of Space Exploration, Space and Society, DOI 10.1007/978-3-319-39827-3_18

The copyright information given in the source line of Chapter 18 was not correct.

The copyright holder of Chapter 18 is "C Frans G. von der Dunk 2016".

The updated original online version for this chapter can be found at 10.1007/978-3-319-39827-3_18

F.G. von der Dunk $(\bowtie)$

College of Law, University of Nebraska-Lincoln, Lincoln, USA

e-mail: fvonderdunk2@unl.edu 